\title{
PENERAPAN MANAJEMEN RESIKO OPERASIONAL PADA PT. BANK PEMBANGUNAN DAERAH SUMATERA BARAT CABANG PAINAN KABUPATEN PESISIR SELATAN
}

\author{
Zico Prasetyo, Afriyeni \\ Akademi Keuangan dan Perbankan Padang \\ Afriyeni.yen@gmail.com
}

\begin{abstract}
The research purpose is to understand the effectiveness of operational risk management on PT. Bank Pembangunan Daerah Sumatera Barat Branch Painan in accordance with the regulation of Bank Indonesia No. 11/25/PBI/2009 about the risk management application on the public bank. The research using descriptive qualitative method by present the of risk management application in a company. The data used are primary data that collected from interview method and the secondary data is action plan of PT. Bank Pembangunan Daerah Sumatera Barat Branch Painan. The research result show that the policy and the procedure and the strategy that applied PT. Bank Pembangunan Daerah Sumatera Barat Branch Painan in risk management application is effective according to the minimal standard of Bank Indonesia and adjusted according to the bank scope of business.
\end{abstract}

Keywords : Risk Management, Operational Risk

\section{LATAR BELAKANG}

Dalam perbankan, baik bank sentral maupun bank umum semakin menyadari bahwa untuk meminimalkan resiko, maka praktek manajemen resiko (risk management) dan tata kelola perusahaan yang baik (good corporate governance) harus dilaksanakan.

Dalam rangka menciptakan prakondisi dan infrastruktur pengelolaan resiko maka bank wajib mengambil langkah-langkah persiapan pelaksanaan pengelolaan resikonya. Untuk itu Bank Indonesia menetapkan Peraturan Bank Indonesia Nomor 11/25/PBI/2009 perubahan atas Peraturan Bank Indonesia Nomor 5/8/PBI/2003 tentang Penerapan Manajemen Resiko pada Bank Umum.

Penerapan Manajemen Resiko (Risk Management) bertujuan untuk menghindari kerugian yang disebabkan terjadinya suatu resiko atau peristiwa. Fokus dari Manajemen Resiko adalah mengidentifikasi, mengelola dan mengendalikan resiko dengan sebaik-baiknya.Dengan demikian PT. Bank Pembangunan Daerah (BPD) Sumatera Barat Cabang Painan tidak terlepas dari berbagai resiko yang dapat mengakibatkan kegagalan usaha bank. 
Pada PT. Bank Pembangunan Daerah (BPD) Sumatera Barat Cabang Painan Penulis menemukan kesalahan pada proses internal, yaitu pada pihak teller yang kurang cekatan dalam melayani nasabah sehingga membutuhkan waktu yang sangat lama yang menyebabkan semakin ramainya nasabah yang antri dan bahkan ada yang sampai berdiri tidak mendapatkan tempat duduk. Tentunya ini sangat mempengaruhi operasional bank walaupun kelihatan sepele tetapi ini juga salah satu faktor kenyamanan nasabah. Nasabah pasti tidak semuanya sabar, tentu ada juga yang tidak. Kekhawatiran penulis hal ini dapat membuat nasabah pindah ke bank pesaing yang pelayanan nya lebih baik.

Pada BPD Sumbar Cabang Painan penulis mendapatkan beberapa data ilmiah di lapangan mengenai permasalahan mengenai pegawai yang mempengaruhi operasional bank bahwa adanya pelatihan karyawan yang tidak terfokus pada bidang kerja yang ditempatinya. Perputaran pegawai yang cukup tinggi juga terjadi sehingga pegawai lama akan dipindahkan dan diganti dengan pegawai baru. Pada beberapa bidang yang harusnya dikerjakan dua orang tetapi dibebankan kepada satu orang sehingga hasil pekerjaan kurang maksimal. Salah satu penyebabnya adalah mutasi pegawai dan belum adanya pengganti.

Permasalahan lain yang penulis ketahui tentang sistem dan teknologi pada BPD Sumbar Cabang Painan adalah masalah jaringan. Kerusakan jaringan terjadi secara mendadak pada waktu tertentu yang mengakibatkan terganggunya pelayanan kepada nasabah.

Dalam kasus yang terjadi Bank BPD Sumbar Cabang Painan tersebut, bahwa terdapat kesalahan manajemen operasional. Berdasarkan data ilmiah diatas, dalam pertimbangan manajemen resiko operasional ini menjadi sangat penting, sehingga nantinya bank dapat meminimalisir resiko dan mendapatkan manfaatnya. Pertimbangannya yaitu manajemen resiko operasional, resiko yang diakibatkan kurangnya informasi dan sistem pengawasan. Dengan demikian kasus yang seperti contoh diatas bisa diminimalisir dengan baik dan tepat.

Berdasarkan uraian latar belakang masalah diatas, maka Penulis mengambil judul "Penerapan Manajemen Resiko Operasional Pada PT. Bank Pembangunan Daerah Sumatera Barat Cabang Painan".

Perumusan Masalah

Adapun rumusan masalah dalam penulisan tugas akhir ini yaitu Bagaimana penerapan Manajemen Resiko operasional pada PT. Bank Pembangunan Daerah Sumatera Barat Cabang Painan?

\section{TINJAUAN PUSTAKA \\ Pengertian Bank}

Adapun pengertian bank menurut Undang-Undang RI Nomor 10 Tahun 1998 tentang Perubahan Undang-undang Nomor 7 Tahun 1992 tentang Perbankan adalah "Badan usaha yang menghimpun dana dari masyarakat dalam bentuk simpanan dan menyalurkannya kepada masyarakat dalam bentuk kredit dan/atau bentuk-bentuk lainnya dalam rangka meningkatkan taraf hidup rakyat banyak". 


\section{Pengertian Resiko}

Menurut Peraturan Bank Indonesia No. 11/25/PBI/2009 Pasal 1 Bagian 4 yang berbunyi resiko adalah potensi kerugian akibat terjadinya suatu peristiwa (events) tertentu.

\section{Jenis Risiko}

Dalam Peraturan Bank Indonesia No. 11/25/PBI/2009 Pasal 4 Ayat (1), yang berbunyi : Resiko sebagaimana dimaksud dalam pasal 2 mencakup :

\section{Manajemen Resiko}

a. Risiko Kredit

b. Risiko Pasar

c. Risiko Likuiditas

d. Risiko Operasional

e. Risiko Hukum

f. Risiko Reputasi

g. Risiko Stratejik

h. Risiko Kepatuhan

Adapun pengertian Manajemen Resiko dalam Peraturan Bank Indonesia No. 11/25/PBI/2009 Pasal 1 bagian 5 yaitu : "Manajemen resiko adalah serangkaian metedologi dan prosedur yang digunakan untuk mengidentifikasi, mengukur, memantau dan mengendalikan resiko yang timbul dari seluruh kegiatan usaha bank".

\section{Ruang Lingkup Manajemen Resiko}

Dalam Peraturan Bank Indonesia No. 11/25/PBI/2009 pada pasal 2 Ayat (1) dan (2) yang berbunyi :

Ayat (1) Bank wajib menerapkan Manajemen Resiko secara efektif, baik untuk bank secara individual maupun bank secara konsolidasi dengan perusahaan anak.

Ayat (2) Penerapan Manajemen Resiko sebagaimana dimaksud pada ayat 1 paling kurang mencakup :

1. Pengawasan aktif Dewan Komisaris dan Direksi

2. Kecukupan kebijakan, prosedur, dan penetapan limit manajemen resiko.

3. Kecukupan proses identifikasi, pengukuran, pemantauan, dan pengendalian resiko, serta sistem informasi manajemen resiko dan

4. Sistem pengendalian intern yang menyeluruh

\section{Pedoman Umum Penerapan Manajemen Resiko}

Sebagai Regulator, Bank Indonesia telah banyak memberikan petunjuk penerapan manajemen resiko dan good corporate governance (tata kelola perusahaan yang sehat) bagi perbankan Indonesia. Dalam Lampiran SE No.5/21/DPNP tanggal 29 September 2003 dijelaskan tentang pedoman umum penerapan manajemen resiko oleh bank sebagai berikut :

Pengawasan Aktif Dewan Komisaris dan Direksi

a. Kewenangan dan tanggung jawab pengurus bank. Bank wajib menetapkan wewenang dan tanggung jawab yang jelas pada setiap jenjang jabatan yang terkait dengan penerapan manajemen resiko. Wewenang dan tanggung jawab dewan komisaris dan direksi. 
b. Sumber Daya Manusia (SDM) . Bank harus menetapkan kualifikasi SDM yang jelas untuk setiap jenjang jabatan yang terkait dengan penerapan manajemen resiko.

\section{Organisasi dan Fungsi Manajemen Resiko}

Dalam rangka penerapan manajemen resiko yang efektif, bank harus menyusun struktur organisasi yang susuai dengan tujuan dan kebijakan usaha, ukuran dan kompleksitas serta kemampuan bank.

Dalam kaitan dengan pengembangan struktur organisasi yang ada, bank wajib membentuk Komite Manajemen Resiko (Risk Management Committe) dan Satuan Kerja Manajemen Resiko (Risk Management Unit).

Kebijakan, Prosedur dan Penetapan Limit Resiko

Kebijakan Manajemen Resiko sekurang-kurangnya meliputi :

Penetapan resiko yang terkait dengan produk dan transaksi perbankan dan Penetapan penggunaan metode pengukuran dan sistem informasi manajemen resiko dalam rangka mengkalkulasi secara tepat eksposur resiko serta aktivitas fungsional bank, dan penetapan pelaporan data dan informasi yang terkait dengan eksposur resiko sebagai input untuk pengambilan keputusan bisnis yang menguntungkan dan tetap memperhatikan prinsip kehati-hatian bank. Penetapan strategi manajemen resiko juga harus mempertimbangkan kondisi keuntungan bank, organisasi bank dan resiko yang timbul sebagai akibat perubahan faktor eksternal dan internal.

Prosedur dan penetapan limit resiko sekurang-kurangnya mencakup Akuntabilitas dan jenjang delegasi wewenang yang jelas, Pelaksanaan kaji ulang terhadap prosedur dan penetapan resiko secara berkala, Dokumentasi dan prosedur penetapan limit yang memadai Penetapan limit resiko wajib mencakup Limit secara keseluruhan, Limit perjenis resiko, Limit peraktivitas fungsional tertentu yang memiliki eksposur resiko.

\section{Proses Penerapan Manajemen Risiko}

\section{Identifikasi Risiko}

Tujuan dilakukannya identifikasi risiko adalah untuk mengidentifikasi seluruh jenis risiko yang melekat pada setiap aktivitas fungsional yang berpotensi merugikan bank

\section{Pengukuran Risiko}

Pendekatan pengukuran risiko digunakan untuk mengukur profil risiko bank. Pendekatan tersebut harus dapat mengukur :

Sensivitas produk/aktivitas terhadapa perubahan faktor-faktor yang mempengaruhinya, baik dalam kondisi normal maupun tidak normal, faktor risiko (Risk Faktors) secara individual, eksposur risiko secara keseluruhan (aggregate), dengan mempertimbangkan risk correlation, seluruh risiko yang melekat pada seluruh transaksi serta produk perbankan dan dapat diintegrasikan dalam sestem informasi manajemen Bank.

\section{Pemantauan Limit Risiko}

Sebagai bagian dari penerapan pemantauan risiko maka limit risiko sekurang-kurangnya memperhatikan kemampuan modal Bank untuk dapat menyerap eksposur risiko atau kerugian yang timbul, dan tinggi rendahnya eksposur Bank, tersedianya limit secara individual dan keseluruhan/konsolidasi, 
mempertimbangkan pengalaman kerugian di masa lalu dan kemampuan sumber daya manusia, memastikan bahwa posisi yang melampaui limit yang telah ditetapkan mendapat perhatian satuan kerja manajemen risiko, komite manajemen risiko dan Direksi.

\section{Sistem Informasi Manajemen Risiko}

Sebagai bagian dari proses manajemen risiko, Bank harus memiliki sistem informasi manajemen risiko yang dapat memastikan terukurnya eksposur risiko secara akurat, informatif, dan tepat waktu, baik eksposur risiko secara keseluruhan/komposit maupun eksposur per jenis risiko yang melekat pada kegiatan usaha Bank, dipatuhinya penerapan manajemen risiko, tersedianya hasil (realisasi) penerapan manajemen resiko dibandingkan dengan target yang ditetapkan oleh bank sesuai dengan kebijakan dan strategi penerapan manajemen resiko.

Sebagai salah satu output sistem informasi manajemen risiko, laporan eksposur risiko disusun secara berkala oleh Satuan Kerja Manajemen Risiko atau sekelompok petugas yang diberikan wewenang

Pengendalian Risiko

Pelaksanan proses pengendalian risiko harus digunakan Bank untuk mengelola risiko tertentu, terutama yang dapat membahayakan kelangsungan usaha Bank.

Pengendalian risiko dapat dilakukan oleh Bank, antara lain dengan cara hedging, dan metode mitigasi risiko lainnya seperti penerbitan garansi, sekuritisasi aset dan credit derivatives, serta penambahan modal Bank untuk menyerap potensi kerugian.

\section{Pengertian Risiko Operasional}

Basel Capital Accord II, resiko operasional didefinisikan sebagai : "Resiko kerugian yang terjadi sebagai akibat dari inadequate atau fail internal process, people and systems or external events"

\section{Identifikasi Resiko Operasional}

Identifikasi resiko operasional dilakukan dengan tujuan untuk mengidentifikasi seluruh jenis resiko yang berpotensi mempengaruhi kerugian operasional dan karenanya juga mempengaruhi laba rugi perbankan.

Identifikasi resiko operasional yang efektif harus memperhatikan semua faktor, baik internal maupu eksternal.

\section{Pengukuran Resiko Operasional}

Pengukuran potensi kerugian resiko operasional dapat dilakukan dengan dua metode :

1. Metode standar

a. Basic Indicator Approach (BIA)

Dalam model BIA bank mempergunakan laba kotor rata-rata tiga tahun terakhir sebagai indikator resiko

b. Standardized Approach (SA)

Untuk menghitung potensi kerugian resiko operasional berdasarkan metode SA diperlukan laba kotor dan parameter beta dari masing-masing bisnis bank. 
c. Alternative Standardized Approach (ASA)

Metode ASA adalah sama dengan metodologi untuk metode SA. Perbedaan nya terletak pada pengukuran untuk resiko operasional untuk business lines retail banking and commercial banking.

2. Metode Internal

Dalam metode internal digunakan pendekatan secara Advanced Measurement Approach (AMA) yaitu metode yang lebih menekankan pada analisis kerugian operasional. Metode ini memerlukan data base kerugian operasional sekurang-kurangnya dua hingga lima tahun terakhir dan perusahan harus mempunyai teknologi yang tinggi sehingga dengan menggunakan bantuan teknologi tersebut dapat dibuat model menangkap, menyeleksi dan melaporkan informasi operasional.

Pemantauan Resiko Operasional

Bagian Manajemen resiko harus melaksanakan pemantauan resiko operasional secara berkala terhadap seluruh eksposur resiko operasional serta kerugian yang dapat terjadi. Dengan menerapkan sistem pengendalian internal yakni menyediakan laporan berkala mengenai kerugian yang ditimbulkan oleh resiko operasional, manajemen perusahaan akan mendapatkan informasi yang jelas tentang potensi kerugian resiko operasional di masa mendatang

Pengendalian Resiko Operasional

Pengendalian dan mitigasi resiko operasional harus dilaksanakan oleh seluruh unit kerja dan satuan kerja bank, termasuk Bagian Manajemen Resiko dan Direksi Bagian manajemen resiko memiliki sistem teknologi informasi sehingga manajemen dapat melaksanakan pemantauan dan pengendalian resiko operasional. Bagian manajemen resiko juga harus memastikan bahwa bank telah memiliki prosedur dan sistem back up, contigency plan, and disaster recovery plan serta sistem keamanan dan warehouse.

\section{Manfaat Manajemen Resiko Operasional (MRO)}

Penerapan terhadap MRO oleh bank memberi manfaat bagi bank (Haris,dkk, 2005 : 27) sebagai berikut :

1. Untuk memastikan bahwa manajemen mengambil langkah yang tepat untuk identifikasi, menilai dan mengelola resiko operasional.

2. Untuk meningkatkan transparansi dan konsistensi atas informasi seluruh organisasi bank dengan menyelaraskan sumber informasi seperti key risk indicator, risk self assesment, corporate loss database dan laporan audit

3. Untuk memfasilitasi pendektatan risk based approach and capital allocation resiko operasional.

4. Untuk mengurangi kerugian operasional

Alat Ukur Manajemen Resiko Operasional

Untuk itu diperlukan alat ukur (Ali, $2006: 418$ ) untuk mendeteksi penyebab resiko operasional tersebut diantaranya :

1. Risk \& Control Self Assesment

Tujuan RSCA adalah untuk meningkatkan pengetahuan dan kesadaran terhadap resiko operasional serta menentukan langkah-langkah untuk memitigasi resiko operasional tersebut, dimana diharapkan dapat menurunkan tingkat kerugian operasional. 


\section{Corporate Loss Database}

Merupakan pusat penyimpanan data kerugian operasional yang dialami bank selama bertahun-tahun yang lalu.

3. Key Risk Indicator

Merupakan suatu kumpulan parameter resiko atas aktivitas operasional yang dilakukan bank

\section{METODE PENELITIAN}

Dalam pengumpulan data dan bahan untuk penelitian ini digunakan metode penelitian sebagai berikut :

Metode Pengumpulan Data

1) Study Lapangan (Field Research)

Peninjauan langsung ke objek yang dipilih untuk meneliti hasil data sekunder. Penelitian langsung ke lapangan ini akan dapat membantu Penulis untuk melengkapi data yang diperlukan. Adapun cara riset lapangan ini adalah dengan mewawancarai langsung pihak-pihak yang berkepentingan dalam hal ini adalah perusahaan dan instansi yang terkait.

2) Study Kepustakaan (Library Research)

Penelitian dilakukan dengan membaca beberapa buku-buku ilmiah dan tulisan-tulisan yang berhubungan dengan pembahasan yang dilakukan.

Metode Analisa Data

Dalam menganalisa data, menggunakan analisa data kualitatif secara deskriptif. Dimana metode kualitatif menggambarkan, memahami dan menjelaskan data yang diteliti selama penelitian berlangsung pada PT. BPD Sumbar Cabang Painan.

\section{HASIL DAN PEMBAHASAN}

Pengawasan Aktif Komisaris dan Direksi

Komisaris dan Direksi PT. BPD Sumbar Cabang Painan telah memahami resiko operasional dan secara aktif mengevaluasi kebijakan dan strategi resiko operasional secara periodik

Kebijakan, Prosedur dan Penetapan Limit

a) BPD Sumbar Cabang Painan memiliki kebijakan pengelolaan resiko operaional yang sesuai dengan misi, strategi bisnis, kecukupan permodalan dan kecukupan sumber daya manusia

b) BPD Sumbar Cabang Painan menetapkan dan menerapkan prosedur untuk menilai resiko operasional

c) Melakukan evaluasi dan pengkinian kebijakan dan prosedur pengelolaan resiko operasional

d) Menetapkan limit (cadangan) resiko operasional dengan mempertimbangkan eksposur resiko dan pengalaman kerugian masa lalu yang diakibatkan oleh resiko operasional.

e) Kebijakan, prosedur dan proses penetapan limit resiko operasional didokumentasikan secara tertulis dan lengkap hingga memudahkan untuk dilakukan jejak audit (audit trail)

1) Penyelesaian Transaksi (Settlement) 
a) BPD Sumbar Cabang Painan melakukan penilaian terhadap tahapan dalam proses penyelesaian transaksi, khususnya mengenai batas akhir perintah pembayaran, batas akhir penerimaan waktu pencatatan pembayaran dana.

b) BPD Sumbar Cabang Painan menyusun suatu prosedur pemantauan penyelesaian transaksi baru atau apabila terdapat transaksi yang belum diselesaikan pembayarannya

c) BPD Sumbar Cabang Painan menyediakan prosedur penyelesaian transaksi yang disebabkan oleh adanya kondisi likuidasi bank yang memburuk

d) BPD Sumbar Cabang Painan melakukan konfirmasi transaksi secara tepat waktu sesuai dengan prosedur yang ditetapkan dan memantau transaksi tersebut secra konsisten

2) Akuntansi

BPD Sumbar Cabang Painan memastikan bahwa penggunaan metode akuntansi adalah sesuai dengan standar akuntansi yang berlaku serta memperhatikan hal-hal sebagai berikut :

a) Melakukan review secara berkala guna memastikan ketetapan metode yang digunakan untuk menilai transaksi

b) Melakukan review secara berkala terhadap kesesuaian metode akuntansi yang digunakan dengan standar akuntansi keuangan yang berlaku

c) Melakukan rekonsiliasi data transaksi secara berkala

d) Mengidentifikasi dan menganalisa setiap ketidakwajaran transaksi yang terjadi

e) Memelihara seluruh dokumen dan arsip yang berkaitan dengan rincian rekening (accounts), sub-ledgers, buku besar (general ledgers), administrasi klasifikasi aset dan dokumentasi pembentukan provisi, guna memudahkan proses jejak audit

3) Inventarisasi Aset dan Kustodian

a) BPD Sumbar Cabang Painan memelihara data akuntansi dan rincian aset pihak ketiga yang dipeliahara/dititipkan (kustodian)

b) BPD Sumbar Cabang Painan memperoleh informasi yang memadai mengenai keaslian penyimpanan/penitipan aset dalam rangka memastikan bahwa aset yang dititipkan tidak memiliki permasalahan hukum

c) BPD Sumbar Cabang Painan melakukan pengecekan secara berkala antara data aset yang dititipkan dengan perjanjian/kontraknya

4) Profil Nasabah dan Prinsip Mengenal Nasabah (Know Your Customer/KYC)

a) BPD Sumbar Cabang Painan menerapkan Prinsip Mengenai Nasabah (KYC) secara konsisten sesuai dengan eksposur resiko operasional.

b) Dalam penerapan KYC tersebut, BPD Sumbar Cabang Painan mewajibkan Customer Service untuk memenuhi seluruh persyaratan dan pedoman tentang Prinsip Mengenal Nasabah (KYC) kepada calon nasabah yang ingin membuka rekening.

5) Profil Karyawan (Employees' Profiles)

BPD Sumbar Cabang Painan memiliki dan menerapkan kebijakan tentang tanggung jawab, kewenangan dan akses pegawai/karyawan terhadap sistem informasi tertentu. Kebijakan tersebut didukung oleh prosedur akses terhadap sistem informasi manajemen, sistem informasi akuntansi, sistem pengelolaan resiko, pengamanan di deadling room, dan ruang pemprosesan data. 
Proses Identifikasi, Pengukuran, Pemantauan dan sistem Informasi Manajemen Resiko Operasional

1) Identifikasi Resiko Operasional

Dalam proses identifikasi resiko operasional BPD Sumbar Cabang Painan, langkah yang dilakukan :

a) BPD Sumbar Cabang Painan melakukan identifikasi dan analisa terhadap faktor penyebab timbulnya resiko operasional yang melekat pada seluruh aktivitas fungsional, produk, proses dan sistem informasi, baik yang disebabkan oleh faktor intern maupun ekstern yang berdampak negatif terhadap pencapaian sasaran organisasi bank.

b) Hasil identifikasi tersebut selanjutnya digunakan oleh BPD Sumbar Cabang Painan untuk mengembangkan suatu database mengenai jenis kerugian (loss event) yang ditimbulkan oleh resiko operasional.

c) Metode yang dapat digunakan BPD Sumbar Cabang Painan untuk mengidentifikasi resiko operasional, antara lain :

1. Self risk assesment berupa checklist untuk mengidentifikasi kekuatan dan kelemahan pada lingkungan operasional Bank,

2. Risk mapping berupa pemetaan menurut jenis resiko terhadap aktivitas fungsional, struktur organisasi dan arus proses transaksi.

3. Key risk indocators berupa statistik atau matriks yang menyediakan data posisi resiko operasional bank, seperti jumlah pembatalan transaksi, tingkat perputaran pegawai, dan frekuensi kesalahan (errors)

4. Scorecards yang menyediakan metode untuk mentranslasikan penilaian/kriteria kualitatif menjadi matriks kuantitatif, yang dapat digunakan untuk mengalokasikan kebutuhan modal masing-masing aktivitas fungsional.

2) Pengukuran Resiko Operasional

a) BPD Sumbar Cabang Painan menilai parameter yang mempengaruhi eksposur resiko operasional, antara lain jumlah dan frekuensi :

1. Kegagalan dan kesalahan sistem;

2. Sistem administrasi;

3. Kegagalan hubungan dengan nasabah;

4. Accounting error;

5. Penundaan dan kesalahan dalam penyelesaian pembayaran;

6. Fraud

7. Rekayasa akunting

8. Strategic failure

b) Pengumpulan Data Resiko Operasional

1. Sumber utama dalam penerapan manajemen resiko operasional adalah data historis mengenai kerugian bank yang disebabkan resiko operasional yang telah divalidasi dan diverifikasi

2. Data kerugian resiko operasional terdiri dari kejadian (events) yang bersifat rutin, berfrekuensi tinggi namun berdampak rendah maupun yang berfrekuensi rendah namun berdampak tinggi terhadap rugi laba bank. Data rendah namun berdampak tinggi.

c) BPD Sumbar Cabang Painan memiliki metodologi pengukuran resiko operasional yang tepat, sumberdaya manusia yang kompeten dan infrastruktur 
sistem yang memadai dalam rangka mengidentifikasi dan mengumpulkan data resiko operasional

d) BPD Sumbar Cabang Painan mencatat dan menatausahakan setiap events termasuk jumlah potensi kerugian yang diakibatkan events dimaksud dalam suatu administrasi data.

2) Pemantauan Resiko Operasional

BPD Sumbar Cabang Painan melakukan pemantauan resiko operasional secara berkelanjutan terhadap seluruh eksposur resiko operasional serta kerugian (loss events) yang dapat ditimbulkan oleh aktivitas fungsional utama (major business line), antara lain dengan cara menerapkan sistem pengendalian intern dan menyediakan laporan berkala mengenai kerugian yang ditimbulkan oleh resiko operasional.

3) Sistem Informasi Manajemen Resiko Operasional

a) BPD Sumbar Cabang Painan memiliki sistem dan teknologi informasi yang memadai.

b) Sistem informasi manajemen menghasilkan laporan yang lengkap dan akurat yang digunakan untuk pemantauan resiko dalam rangka mendeteksi dan mengkoreksi penyimpangan secara tepat waktu dalam rangka proses pengambilan keputusan oleh direksi guna mengurangi potensi terjadinya loss events

Pengendalian Resiko Operasional

1) BPD Sumbar Cabang Painan memiliki kebijakan, prosedur dan proses untuk mengendalikan atau memitigasi resiko operasional, sesuai dengan komplesitas operasional bank

2) Dalam penerapan pengendalian resiko operasional, BPD Sumbar Cabang Painan mengembangkan proses untuk memitigasi resiko operasional antara lain pengamanan proses teknologi informasi, asuransi, dan outsourching sebagian kegiatan operasional bank.

3) Dalam hal bank mengembangkan pengamanan proses teknologi informasi, BPD Sumbar Cabang Painan memastikan tingkat keamanan dari electric data processing.

4) Pengendalian terhadap sistem informasi harus memastikan :

a) Adanya penilaian berkala terhadap pengamanan sistem informasi, yang disertai dengan tindakan korektif apabila diperlukan.

b) Tersedianya prosedur back up untuk menjamin berjalannya kegiatan operasional bank dan mencegah terjadinya gangguan yang signifikan.

c) Tersedianya prosedur back-up dan rencana darurat (contigency plan) yang diuji secara berkala.

d) Tersedianya penyimpanan informasi dan dokumen yang berkaitan dengan analisa, programming, dan pelaksanaan pemrosesan data.

5) BPD Sumbar Cabang Painan memiliki support system, yang sekurangkurangnya mencakup :

a) Identifikasi error secara dini

b) Pemrosesan dan penyelesaian seluruh transaksi secara efisien, akurat dan tepat waktu

c) Kerahasiaan, kebenaran serta keamanan transaksi. 
6) BPD Sumbar Cabang Painan melakukan kaji ulang secara berkala terhadap prosedur, dokumentasi, sistem pemrosesan data, contigency plan, dan praktek operasional lainnya guna mengurangi kemungkinan terjadinya kesalahan manusia (human error) yang menimbulkn resiko operasional.

Contoh Kasus Resiko Operasional

1. Kasus 1

Pada tangggal 07 Januari 2013 nasabah datang ke BPD Sumbar Cabang Painan dengan maksud ingin melakukan penyetoran ke rekening anaknya sebesar Rp. 2.250.000 dengan keadaan kantor yang sedang dipenuhi oleh nasabah lain, nasabah A ikut mengantri. Setelah cukup lama mengantri nasabah A dipanggil oleh teller. Kemudian teller menanyakan ke nasabah A maksud dan tujuan transaksinya. Setelah memberikan tanda setoran ke teller, kemudian teller melakukan input data ke komputer sesuai dengan tanda setoran yang diberikan oleh nasabah A setelah menunggu beberapa lama transaksi nasabah A selesai dilakukan. Dengan mengambil bukti setoran yang diberikan oleh teller nasabah A kemudian meninggalkan kantor BPD Sumbar Cabang Painan.

Kemudian pada tanggal 08 Januari 2013 nasabah A kembali mendatangi kantor BPD Sumbar Cabang Painan dengan maksud mengkonfirmasikan kepada pihak bank bahwa transaksi penyetoran yang dilakukannya pada tanggal 07 Januari 2013 tidak sampai ke rekening anaknya. Padahal bukti sertoran dan uang telah diserahkan kepada petugas bank yaitu teller. Dengan bukti setoran yang ada pada nasabah A, nasabah A kemudian melakukan komplain kepada pihak bank. Dari bukti setoran yang ada pada pihak bank dan nasabah A, pihak bank melakukan pengecekan. Setelah dilakukan pengecekan ternyata terjadi kesalahan antara bukti validasi (Tapak validasi) yang dilakukan oleh teller ternyata berbeda dengan yang dibuat nasabah.

Dampak dari Kasus 1

Adapun dampak dari kasus 1 yang terjadi diatas adalah :

1) Kesalahan validasi dapat mengurangi kepercayaan nasabah terhadap bank

2) Bagi petugas bank yakni teller kasus tersebut dapat mengurangi kinerja bank dari teller yang melakukan kesalahan karena kurangnya kehati-hatian dari teller

3) Jika kasus tersebut tidak dapat diselesaikan sudah pasti nasabah akan mengalami kerugian financial (sejumlah uang yang disetorkan)

4) Jika nasabah tetap melakukan komplein dan ternyata uang yang disetorkan telah diambil oleh pemilik rekening, dan ternyata tidak dapat dikembalikan, hal ini mendatangkan kerugian bagi teller karena teller harus mengganti uang tersebut karena hal tersebut merupakan tanggung jawab teller.

Penyelesaian dari Kasus 1

Ada beberapa langkah yang dapat dilakukan oleh pihak bank ataupun nasabah untuk menyelesaikan kasus seperti diatas, yakni :

1. Pihak bank yakni BPD Sumbar Cabang Painan segera menghubungi bank yang mewakili nomor rekening yang telah dituju/validasi oleh teller dan membuat surat pernyataan, kemudian mengkonfirmasi bahwa telah terjadi kesalahan validasi. Kemudian bank yang bersangkutan diminta untuk mencari nasabah pemilik rekening tersebut. Bank mengkonfirmasikan nasabah telah terjadi 
kesalahan validasi ke rekening bank yang bersangkutan untuk melakukan pengembalian uang ke BPD Sumbar Cabang Painan.

2. Penyelesaian yang kedua adalah penyelesaian yang paling akhir diambil karena langkah ini merupakan langkah yang merugikann teller, yakni teller harus mengganti kerugian yang diderita nasabah A, karena kesalahan datang dari pada teller yang telah salah memasukkan nomor rekening nasabah ke sistem. Langkah ini diambil jika nasabah pemilik rekening setelah dikonfirmasi ternyata tidak bisa dikembalikan dengan alasan telah dipergunakan.

Antisipasi dari Kasus 1

Adapun beberapa tindakan yang dapat dilakukan untuk mengantisipasi dan mengurangi kasus tersebut, yakni :

1. Teller harus mengkonfirmasikan kepada nasabah atas tanda setoran yang telah ditulis sebelumnya

2. Setelah melakukan verifikasi awal dengan melakukan pengecekan dan pencocokan terhadap :

a. Nomor rekening hasil validasi dengan yang ditulis nasabah

b. Nama pemilik rekening

c. Jumlah nominal dan terbilang yang ditulis nasabah

d. Pemberian tanda tangan yang dibuat oleh nasabah (khusus penarikan tabungan harus cocok dengan yang ada di buku tabungan)

e. Tanggal transaksi

3. Overbooking

Adalah kegiatan transaksi dari satu rekening ke rekening lainnya tanpa mempengaruhi keadaan kas teller

4. Rekening titipan

Adalah rekening penampung yang harus dimiliki oleh BPD Cabang yang dapat dipergunakan untuk melakukan transaksi antar cabang BPD Sumbar.

2. Kasus 2

Pada tanggal 30 Maret 2016 ketika nasabah BPD Sumbar Cabang Painan sedang ramai untuk menarik uang dan menyetor uang terjadi gangguan sistem yang diakibatkan oleh jaringan yang tidak stabil. Oleh karena itu nasabah semakin ramai, sampai ada nasabah yang berdiri tidak dapat tempat duduk menunggu jaringan pulih kembali. Karena nasabah di akhir bulan memang sangat ramai menarik uang di BPD Sumbar Cabang Painan. Ada yang dari instansi pemerintahan dan pencairan dana tender serta untuk keperluan lain. Dengan adanya gangguan jaringan tersebut maka akan terjadi ganguan pelayanan yakninya keterlambatan nasabah dalam pengambilan uang atau penyetoran uang. Maka dari itu banyak nasabah yang komplen ke pihak bank karena tidak sedikit nasabah memerlukan uang yang akan dicairkan atau disetor perlu cepat.

Dampak dari Kasus 2

Adapun dampak dari kasus 2 diatas adalah:

1. Gangguan jaringan dapat mengurangi kepercayaan nasabah terhadap bank.

2. Jika kasus ini terus terjadi bukan tidak mungkin nasabah akan berpindah ke bank lain yang pelayanan nya lebih baik 
Penyelesaian dari Kasus 2

Penyelesaian yang dilakukan oleh BPD Sumbar Cabang Painan yakni pihak bank berusaha menghubungi otoritas yang berwenang dan mengkonfirmasikan bahwa ada gangguan jaringan yang mengakibatkan terganggunya transaksi bank.

BPD Sumbar Cabang Painan memberitahu kepada nasabah bahwa telah terjadi gangguan jaringan dan pihak bank meminta nasabah untuk bersabar sebentar karena akan segera pulih.

\section{SIMPULAN}

Secara keseluruhan penerapan manajemen resiko operasional pada PT. Bank Pembangunan Daerah Sumatera Barat Cabang Painan telah sesuai dengan Peraturan Bank Indonesia No. 11/25/PBI/2009 yang telah dilaksanakan secara efektif. Proses penerapan manajemen resiko operasional pada BPD Sumbar Cabang Painan adalah penerapan yang sesuai dengan konsep-konsep yang ditetapkan oleh Bank Indonesia. PT. BPD Sumbar Cabang Painan secara umum mampu mengendalikan resiko operasional.

. Pada BPD Sumbar Cabang Painan telah menyediakan sumber daya yang berkualitas untuk menyelesaikan tugas pengelolaan secara efektif dengan cara berkala mengirim pegawai untuk mengikuti pelatihan dan ujian sertifikasi manajemen resiko. Dimana pemimpin cabang dan semua pemimpin seksi telah dinyatakan lulus sertifikasi manajemen resiko.

BPD Sumbar Cabang Painan memberikan penilaian kepada karyawannya dengan memasukkan setiap kesalahan dalam kegiatan operasional ke dalam item kesalahan karyawan yang melakukan kesalahan. Dan hal ini akan mengurangi penilaian terhadap karyawan tersebut. Melalui ini secara tidak langsung akan membuat karyawan untuk tidak melakukan kesalahan lagi.

Jadi, dengan demikian BPD Sumbar Cabang Painan sudah menerapkan manajemen resiko sesuai dengan Peraturan Bank Indonesia No. 11/25/PBI/2009. Implementasi manajemen resiko tersebut telah sejalan dengan rekomendasi yang dikeluarkan oleh Bank International Settlements melalui Basel committe on Banking Supervision sebagaimana diwajibkan oleh bank indonesia melalui Peraturan Bank Indonesia tentang penerapan manajemen resiko.

\section{DAFTAR PUSTAKA}

Ali, H Masyud. 2006. Manajemen Resiko. Jakarta : PT. Raja Grafindo Persada.

Fahmi, Irham. 2011. Manajemen Resiko. Bandung. Alfabeta CV.

Fernandes, Y. D., \& Marlius, D. (2018). Peranan Customer Service Dalam Meningkatkan Pelayanan Kepada Nasabah Pada PT. Bank Pembangunan Daerah Sumatera Barat Cabang Utama Padang. https://doi.org/10.31227/osf.io/wrh3p 
Handoko, Sri Redjeki. 1995. Teori dan Perilaku Organisasi Perusahaan. Yogyakarta : BPFE

Haris, Arifin. S. 2005. Manajemen Resiko dan Manajemen Resiko Perbankan. Jakarta : Prima Management Consultan

Herman, Darmawi. 2011. Manajemen Perbankan. Jakarta : Bumi Aksara.

Kasmir. 2014. Manajemen Perbankan. Edisi Revisi, PT. Raja Grafindo Persada

Muslich. 2007. Manajemen Resiko Operasional. Jakarta : Bumi Aksara.

Peraturan Bank Indonesia No. 11/25/PBI/2009 Perubahan atas Peraturan Bank Indonesia No. 5/8/PBI/2003 Tentang Penerapan Manajemen Resiko.

Sinungan, Sondang P. 2001. Manajemen Dana Bank. Jakarta : Bumi Aksara

Susilo, Y. Sri. 2001. Bank dan Lembaga Keuangan Lainnya. Jakarta : PT. Gramedia Pustaka Utama.

Umar. 2001. Manajemen Bank. Jakarta : Pustaka Grafiti.

Undang - undang No. 10 Tahun 1998 Tentang Perubahan Undang - undang No.7 Tahun 1992 Tentang Perbankan.

Wulandari, R., \& Susanto, R. (2019). Penerapan Manajemen Risiko Operasional Pada Unit Teller Pada PT. Bank Pembangunan Daerah Sumatera Barat Cabang Lubuk Alung. https://doi.org/10.31219/osf.io/pjgch 